\title{
Operatory metatekstowe w funkcji wskazówek organizacji tekstu w telewizyjnej relacji na żywo
}

\section{Metatext markers as text organization signals in television live report}

\author{
Agnieszka Czoska*, Agata Karaśkiewicz** \\ * Instytut Psychologit, UNIWERsytet IM. ADAMA MiCKIEWICZA \\ aczoska@amu.edu.pl \\ ** INSTYTUT JęZYKOZNAWSTWA, UNIWERSYTET IM. AdAMA MICKIEWICZA \\ AL. NiEPODLEGLOŚCI 4, 61-874 POZNAŃ \\ agata.karaskiewicz@wp.pl
}

\begin{abstract}
Abstrakt
The article presents a study of the use of metatext markers for signalling the structure of television live report. The study is aimed at analysing how reporters organize their messages with metatextual elements. A corpus of live reports form polish news bulletins was used. The list of metatext markers was based on metadiscourse classifications by Hyland (2005), Dahl (2004) and Ädel (2006) and extended with propositions of the authors..
\end{abstract}

Artykuł ten powstaje na bazie zainteresowań językiem telewizji. Poruszone będą zagadnienia dotyczące funkcji operatorów metatekstowych w organizacji krótkich wypowiedzi w monologu telewizyjnym w postaci krótkich relacji na żywo (RNŻ). W przypadku takiego komunikatu, mamy do czynienia ze specyficzną sytuacją komunikacyjną: nadawcy i odbiorcy są od siebie oddzieleni przestrzennie oraz czasowo, komunikacja jest jednokierunkowa i asymetryczna (Miodunka i Ropa, 1979, s. 69). Jednakże głównym czynnikiem decydującym o odmienności tekstu powstającego w czasie w RNZ od pozostałych tekstów w telewizji (,tam-wtedy”), jest bezpośredniość oraz nadawanie jej z miejsca zdarzenia („tu i teraz”) (Montgomery, 2007). Jest przedmiotem dyskusji, na ile występ reportera jest improwizowany. $Z$ jednej strony reporter zna wcześniej temat relacji, ma czas na zebranie informacji na miejscu zdarzenia, porozmawianie ze świadkami, etc., powinien zatem przemyśleć jej strukturę, zawartość treściową i językową. Z drugiej strony, szybkie tempo realizacji przekazu sprawia, że nie wszystko można przewidzieć. Zasadne wydaje się więc pytanie, w jaki sposób stojąc przed kamerą, tworząc tekst W chwili przekazu, reporter organizuje dyskurs, łączy następujące po sobie części RNŻ czy zapowiada przykłady. 


\section{Tho teoretyczne}

Przegląd badań korpusowych nad językiem mówionym wskazuje na niewielkie zainteresowanie badaczy operatorami metatekstowymi rozumianymi jako wskazówki struktury i organizacji tekstu. Tylko nieliczne prace poświęcone zostały badaniu wyrażeń metatekstowych-leksykalnych spoiw dialogu telewizyjnego, w oparciu o rejestrowane wcześniej wywiady i dyskusje prowadzone w studiu telewizyjnym (Winiarska, 2001). Nieznane są autorkom prace nt. operatorów metatekstowych sytuujących się wewnątrz krótkiej wypowiedzi jednej osoby, porządkujących nadawany „na żywo” komunikat medialny. Monolog w postaci RNŻ, który cechuje się ,zaburzeniami ciągłości wypowiedzi”, tj. wahaniami, błędami czy poprawianiem się (Montgomery, 2005) oraz obecnością kontekstu ekranowego, prawdopodobnie nie został do tej pory szerzej zbadany. Tymczasem można oczekiwać, że pojawienie się w komunikacie określonych wyrażeń metatekstowych, współuczestniczących w organizowaniu tekstu mówionego w postaci RNŻ, tworzy dla widzów pewne wskazówki, odsyłające do tego, co już powiedziano, do tego, co nastąpi, lub w bok (do tego co mogłoby zostać powiedziane - Winiarska, 2001), czyniąc wypowiedź mniej lub bardziej spójną.

\section{Relacja na żywo}

Relacje na żywo (RNŻ), czyli relacje ze zdarzeń rozgrywających się w czasie rzeczywistym, są - obok newsów - standardowym sposobem przekazywania informacji, znajdziemy je w każdym serwisie informacyjnym. W Polsce początki nadawania RNŻ zainicjowano 11. września 2001. roku $\mathrm{z}$ USA, podając informacje o zamachach w Nowym Jorku i Waszyngtonie. Relacja ze zdarzeń rozgrywających się w czasie rzeczywistym to łączenie podczas programu na żywo z reporterem, który jest na miejscu omawianych wydarzeń (Uszyński, 2004). Reporter pełni funkcję przekaźnika między miejscem zdarzenia a widzami zgromadzonymi przed telewizorami. Jego zadaniem jest „danie świadectwa”, które powinno wywołać reakcje widzów (Skworz i Niziołek ,2010, s. 210-211).

Z uwagi na warunki powstawania, język RNŻ mogą cechować zaburzenia płynności (wahania, anakoluty, konstrukcje niespójne semantycznie lub zaburzone składniowo, czy nawet nagłe zmiany toku wypowiedzi (Montgomery, 2005).

Z drugiej strony, w przypadku RNŻ, mimo formułowania wypowiedzi w momencie mówienia i konieczności improwizacji, reporterzy przygotowują się do zdawania relacji, a jej temat zostaje wcześniej ustalony. Dlatego też teksty „na żywo" zalicza się do grupy „przekazów opracowanych” (Miodunka i Ropa, 1979). Nadawca monologu w postaci RNŻ (reporter), świadomy swojego wystąpienia przed kamerą i widzami (zbiór odbiorców nie jest pusty - Lubaś, 1979), powinien przygotować się do niego wcześniej, tj. zaplanować cały tekst, przemyśleć jego strukturę oraz zawartość treściową i językową (Grabias, 1997, s. 287). 
Agnieszka Czoska, Agata Karaśkiewicz: Operatory metatekstowe w funkcji wskazówek organizacji tekstu mówionego w monologu telewizyjnym

Tabela 1.: Różnice ze względu na rodzaj przekazu (Montgomery, 2005) oraz obserwacje własne (Karaśkiewicz, 2012)

\begin{tabular}{|c|c|c|}
\hline KATEGORIA & $\overline{\mathrm{RNZ}}$ & NEWS \\
\hline $\begin{array}{l}\text { Forma/ Sposób } \\
\text { przedstawiania }\end{array}$ & mówiona & czytany \\
\hline Miejsce nadawania & $\begin{array}{l}\text { miejsce (okolice) w którym } \\
\text { doszło do zdarzenia }\end{array}$ & studio \\
\hline $\begin{array}{l}\text { Warstwa językowa/ } \\
\text { język }\end{array}$ & $\begin{array}{ll}\text { mniejsza } & \text { "staranność } \\
\text { językowa” } & \text { - wahania, } \\
\text { poprawianie się, pomyłki, } \\
\text { pauzy wypełnione, }\end{array}$ & $\begin{array}{l}\text { brak wahania, rzadko } \\
\text { poprawianie się, pomyłki, } \\
\text { brak pauz wypełnionych }\end{array}$ \\
\hline Montaż & $\begin{array}{l}\text { prezentowana na żywo; brak } \\
\text { możliwości ingerencji w } \\
\text { słowo, obraz, dźwięk; nie } \\
\text { ma moźliwości } \\
\text { przeredagowania, montażu; } \\
\text { filmowane zdarzenie } \\
\text { nadawane jest jako } \\
\text { continuum, bez cięć } \\
\text { montażowych }\end{array}$ & $\begin{array}{l}\text { poddany obróbce przed } \\
\text { emisją: korekcie, zmianom } \\
\text { - montażowi; ingerencja } \\
\text { „wyżej postawionych” w } \\
\text { strukturze redakcji -decyzja } \\
\text { o ostatecznym kształcie } \\
\text { newsa i jego emisji }\end{array}$ \\
\hline $\begin{array}{l}\text { Możliwości } \\
\text { techniczne/ } \\
\text { Technologia? }\end{array}$ & $\begin{array}{l}\text { mniejsze - technologicznie } \\
\text { możliwe pokazywanie } \\
\text { dodatkowych elementów } \\
\text { graficznych na ekranie w } \\
\text { czasie trwania relacji, } \\
\text { jednak rzadko stosowane } \\
\text { (tylko w sytuacji, gdy } \\
\text { reporter ma moźliwość } \\
\text { wcześniejszego } \\
\text { przygotowania) }\end{array}$ & $\begin{array}{l}\text { większe - pojawiają się } \\
\text { fragmenty dokumentów, } \\
\text { cytatów, sondy, komentarze } \\
\text { (intertekstualność) }\end{array}$ \\
\hline Struktura & $\begin{array}{ll}\text { relacjonowana } & \text { zgodnie } \\
\text { zasadami } \\
\text { piramidy" }\end{array}$ & $\begin{array}{l}\text { większa dowolność - wedle } \\
\text { wizji } \\
\text { dziennikarza/ewentualnie } \\
\text { oczekiwań redakcji }\end{array}$ \\
\hline Cechy & nacechowana modalność & nienacechowana modalność \\
\hline & stwierdzenia „możliwości” & stwierdzenia faktów \\
\hline & $\begin{array}{l}\text { większa improwizacja oraz } \\
\text { spontaniczność }\end{array}$ & istnienie „scenariusza” \\
\hline Reporter & widoczny „na wizji” & $\begin{array}{l}\text { nie pojawia się w newsie, } \\
\text { za wyjątkiem ,stand'upa" }\end{array}$ \\
\hline & $\begin{array}{lr}\text { Jego obecność } & \text { ma } \\
\text { uwiarygodnić } & \text { przekaz; } \\
\text { przekazuje } & \text { atmosferę, } \\
\text { emocje; wtrąca } & \text { autorskie } \\
\text { stanowisko } & \\
\end{array}$ & $\begin{array}{l}\text { przedstawia fakty; brak } \\
\text { stronniczości }\end{array}$ \\
\hline Funkcja & $\begin{array}{l}\text { dopełnienie ,surowych } \\
\text { faktów”, zaimprowizowanie } \\
\text { komentarza na bazie faktów } \\
\text { już przedstawionych; } \\
\text { domniemania, spekulacje }\end{array}$ & przedstawienie \\
\hline
\end{tabular}




\section{Operatory metatekstowe w funkcji organizacji tekstu}

Operatory metatekstowe (Winiarska, 2001; Misztal, 2010) są w niniejszym badaniu rozumiane jako podzbiór elementów pełniących w danym tekście (pisanym lub mówionym) funkcję metatekstową (Jacobson, 1989). Wyrażenia takie zaliczane są do metatekstu - zbioru elementów tekstu odnoszących się do samego tekstu, a nie opisywanej w nim rzeczywistości (według niektórych definicji elementy te nie dodają niczego do treści tekstu - Frazer, 1998). Kategorią nadrzędną w stosunku do metatekstu jest metadyskurs, obejmujący elementy tekstu związane $\mathrm{z}$ interakcją nadawca-odbiorca (Hyland, 2005; Ädel, 2006).

Podawane w literaturze dokładne definicje metatekstu i operatorów metatekstowych mogą znacznie różnić się zasięgiem. Najszerszą definicję stosuje Lemarié i in. (2008) zaliczając do metatekstu wszystkie środki organizacji tekstu, w tym także graficzne. Nieco węższą, ograniczającą metatekst do językowych wskazówek struktury tekstu czy nastawienia autora, podaje Hyland $(1998,2005)$, skupiając się na interakcyjności wyrażeń tego typu. Najwęższą definicję metatekstu z cytowanych tu autorów proponuje Ädel (2006): wyrażenia dotyczące tekstu (jako tekstu), nadawcy (jako autora tekstu) oraz odbiorcy (jako czytelnika lub słuchacza tekstu), charakteryzujące się zwrotnością (reflexivity) oraz pełniące funkcję metatekstową explicite. Podejście to zostało opracowane na potrzeby badań korpusowych. Dla potrzeb niniejszej pracy przyjęta zostanie definicja zaproponowana przez Ädel, ponieważ podejście to jest najdokładniej zoperacjonalizowane.

Najważniejszym elementem wąskiej definicji metatekstu (Ädel, 2006) jest warunek eksplicytności (explicitness). Umożliwia to stworzenie listy potencjalnych operatorów metatekstowych bez uprzedniego odwoływania się do badanych tekstów (pozwala więc zachować szersza perspektywę badawcza i nie ograniczać listy operatorów metatekstowych do występujących w tekstach danego typu). Operator metatekstowy musi, według tej definicji, wprost odnosić się do wypowiedzi z wykorzystaniem, na przykład, etykiet (Lemarié i in., 2008) - nazw jego elementów składowych (np. „wypowiedź”, „zdanie”, ,podsumowanie”), wskazywać akty komunikacyjne (np. „opisać”, „słyszeć”), relacje retoryczne (,jak wynika”, „oznacza to”), uporządkowanie (,po pierwsze”, „następnie”). Wąska definicja metatekstu została wykorzystana w opisywanym badaniu także dlatego, że pozwala oddzielić wyrażenia metatekstowe od intertekstowych, metadyskursowych - interpersonalnych lub interakcyjnych w rozumieniu Hylanda (1998, 2005), wskazówek podkreślenial (attitude markers) i nastawienia autora2 (stance markers). Wydaje się to istotne w kontekście analiz tekstów mówionych i stanowi dodatkowy argument za wyborem definicji Ädel (2006) do analizy

Wyrażenia wskazujące na istotność danego fragmentu dla całego tekstu lub jego części, na przykład „co ważne”, „należy zauważyć”, „chciałbym podkreślić”. Można tu zaliczyć także wyrażenia wskazujące na to, czy dany wątek jest głównym czy pobocznym elementem tekstu (np. „na marginesie”).

2 Wskazówki stanu mentalnego autora: „myślę”, „sądzę”, „uważam”, „wiem”, „wątpię”. 
Agnieszka Czoska, Agata Karaśkiewicz: Operatory metatekstowe w funkcji wskazówek organizacji tekstu mówionego w monologu telewizyjnym

stosowania operatorów metatekstowych jako wskazówek organizacji RNŻ mimo, że jej badanie dotyczyło metatekstu w tekstach pisanych.

Metatekst wyodrębniony według opisanej powyżej metody można zaliczyć do następujących klas wyrażeń metatekstowych w najczęściej cytowanej w badaniach nad metadyskursem klasyfikacji Hylanda (1998, 2005):

1. markerów logicznych;

2. markerów endoforycznych (anaforycznych i kataforycznych, wskazujących fragmenty tekstu);

3. markerów aktów dyskursowych;

4. markerów synonimiczności lub uszczegółowienia.

Wszystkie te klasy należą do metadyskursu tekstowego (interaktywnego), czyli właściwego metatekstu w terminologii Hylanda. Dahl (2004) korzystając z klasyfikacji Hylanda w swoich badaniach korpusowych wskazała możliwość podziału tak opisywanego metatekstu na lokalizacyjny (niosący informację o położeniu obiektów tekstowych) oraz retoryczny (niosący informację o charakterze relacji między wskazywanymi fragmentami).

W opisywanym tu badaniu zostały także uwzględnione cechy operatorów metatekstowych wskazywane przez Lemarié i in. (2008) jako kluczowe dla zrozumienia metatekstu (Lemarié i in., 2008; Lorch, Lemarié, Grant, 2011):

1. funkcja informacyjna (information function);

2. zasięg (scope) - globalny lub lokalny;

3. forma (realization);

4. położenie (location) - przed lub po obiekcie odniesienia.

Autorzy wymieniają sześć funkcji informacyjnych, które mogą być spełniane przez wyrażenie metatekstowe (Lemarié i in., 2008, s. 32-33):

1. demarkacyjna;

2. organizacyjna;

3. etykietowanie;

4. wskazywanie funkcji danego wyrażenia w tekście;

5. wskazywanie tematu;

6. podkreślenie (emphasis).

Analizy stosowania w tekście leksykalnych wskazówek jego organizacji i spójności uwypuklają $\mathrm{z}$ jednej strony rolę metatekstu jako instrukcji przetwarzania tekstu (Hyland, 2005), z drugiej strony mogą wskazywać na charakter struktury tekstu - liniowy lub nie (Dahl 2004, Mur-Dueñas 2011) czy jego spójność lokalną i globalną (lub jej brak). Poza tym, jak wskazuje Dahl (2004) w swojej analizie artykułów naukowych, im lepiej określony jest standard konstrukcji tekstu w danej dziedzinie (co wiąże się z „dojrzałością” dziedziny), tym mniej autorzy koncentrują się na samym tekście, w związku z czym stosują mniej metatekstu.

Operatory o funkcji organizacyjnej wydają się być bardzo zróżnicowane pod względem położenia i zasięgu (Czoska, 2011), co może stanowić podstawę do analizy metatekstu jako instrukcji nadawcy co do struktury tekstu, podawanej, gdy nadawca sądzi, że odtworzenie zamierzonej struktury jest konieczne do zrozumienia komunikatu (Hyland, 2005). Autor może postrzegać wypowiedź jako zaplanowaną całość i uwzględniać elementy mające się dopiero pojawić. Może 
też wskazywać treści już znane odbiorcy jako kontekst lub wiedza współdzielona (common ground) istotne do zrozumienia następnych fragmentów (Fetzer i Fisher, 2007). Jednocześnie położenie operatorów może wskazać na styl argumentacyjny autora tekstu (Dahl, 2004): proaktywny, gdy przeważają operatory kataforyczne lub retroaktywny - z przewagą operatorów anaforycznych.

\section{Badanie wystąpień operatorów metatekstowych w RNŻ}

Celem podjętych badań jest określenie w jaki sposób reporter, występujący przed kamerą na żywo $\mathrm{w}$ serwisie informacyjnym, za pomocą operatorów metatekstowych organizuje komunikat. Zasadniczym celem jest eksperymentalna eksploracja oraz określenie dominujących tendencji w sposobie hierarchizacji, strukturalizacji, uwypuklania rozkładu informacji, a także porządkowania powstającego dyskursu przekazów reporterskich w postaci telewizyjnego monologu RNŻ. Charakterystyka organizacji przekazu obejmuje analizę ilościową oraz jakościową metatekstu - wyrażeń explicite metatekstowych (Ädel, 2006), stanowiących wskazówki struktury tekstu (mających funkcję organizacyjną), należących głównie do markerów endoforycznych, markerów aktów dyskursowych oraz wskazówek uporządkowania i uszczegółowienia lub synonimiczności (Dahl, 2004; Mur-Dueñas, 2011). Analizie poddane zostaną także położenie i zasięg (Lemarié i in., 2008) znalezionych operatorów.

Przyjęto następujące hipotezy badawcze:

1. Ze względu na krótki czas trwania RNŻ, będą $\mathrm{w}$ nich przeważać operatory lokalne,

2. Z uwagi na obowiązujący standard struktury informacyjnej RNŻ (odwrócona piramida), markery kataforyczne (zapowiadanie eksplikacji) będą stosowane częściej niż anaforyczne,

3. Najczęściej stosowanymi typami operatorów będą markery endoforyczne i wyliczenia - najliczniejsze w tekstach pisanych w języku polskim (Czoska, 2011, s.9).

\section{Metoda badań}

\subsection{Ogólna charakterystyka materiału}

Podstawą materiałową dla niniejszych badań jest 45 wypowiedzi telewizyjnych, w odmianie mówionej monologowej, w postaci RNŻ. Wszystkie pochodzą z oryginalnych ogólnopolskich telewizyjnych programów informacyjnych emitowanych codziennie w TVN, TVN24, Polsat News, a także w kanałach lokalnych: TVP Info oraz w telewizji WTK. Kryterium wyboru stacji telewizyjnych, dla celów analizy przeprowadzonych w niniejszym opracowaniu, stanowiła zarówno oglądalność (TVN24, Polsat News) (Boyd, 2006, s. 183), jak i stopień dostępności archiwizowanych materiałów (WTK, TVP Info). Treści przekazów są różnorodne: dotyczą polityki, ekonomii, społeczeństwa oraz kultury. Przekazy - zachowują bardzo podobną kompozycję. Kontekst RNŻ obejmuje pełną relację reportera $\mathrm{z}$ miejsca zdarzenia wraz $\mathrm{z}$ białą, czyli zapowiedzią przekazu lub pytaniem prowadzącego ze studia (Uszyński, 2004). 
Agnieszka Czoska, Agata Karaśkiewicz: Operatory metatekstowe w funkcji wskazówek organizacji tekstu mówionego w monologu telewizyjnym

\subsection{Przebieg nagrań oraz tworzenie korpusu transkryptów}

Materiał został zarejestrowany w okresie jednego roku kalendarzowego: od lipca 2010 do lipca 2011 roku.

RNŻ rejestrowane były kilkanaście razy $\mathrm{w}$ miesiącu $\mathrm{w}$ różnych dniach tygodnia, o różnych porach. Materiał był nagrywany na płyty DVD. Po dokonaniu wstępnej selekcji odrzucono materiał, który nie spełniał wstępnych założeń technicznych. RNŻ dobierane były według pewnego klucza: analizie poddawane są wyłącznie przekazy bez udziału innych rozmówców (np. w formie dialogu, polilogu), setek, rozmów telefonicznych (zob. tab. 2). RNŻ spełniające wyznaczone kryteria zostały ponumerowane i 45 spośród nich wybrano losowo do analizy.

Liczba RNŻ przypadających na daną stację telewizyjną nie jest taka sama i wynika $\mathrm{z}$ ich dostępności $\mathrm{w}$ okresie rejestracji. Z uwagi na podobną strukturę, przyjmuje się że RNŻ pochodzące $\mathrm{z}$ różnych stacji stanowią grupę stosunkowo jednorodną ze względu na badane tutaj cechy. Za nieistotną dla prowadzonych analiz uznano także tematykę RNŻ, materiał nie był więc dobierany pod tym kątem.

Nagrania transkrybowano ortograficznie z podziałem na wyrazy tekstowe. Zapis prowadzono według zasad współczesnej ortografii języka polskiego, z pominięciem interpunkcji. Każdy wyodrębniony wyraz zapisano w takiej formie morfologicznej, w jakiej użył go mówiący. Transkrypcji nagrań dokonano na dwa sposoby:

Przy użyciu programu Praat $^{3}$ przetranskrybowano 23 nagrania fonii (wcześniej wyodrębniono fonię w celu transkrybowania wypowiedzi werbalnej).

Przy użyciu programu Writer $\mathrm{z}$ pakietu OpenOffice dokonano 22 transkrypcji.

Tabela 2 przedstawia rodzaje RNŻ ze względu na formę oraz pełnioną funkcję (Karaśkiewicz, 2012).

Program przeznaczony do analiz akustyczno-fonetycznych autorstwa Paula Boersmy i

Davida Weeninka (2001). 
Tabela 2.: Rodzaje RNŻ: klasyfikacja ze względu na formę (Karaśkiewicz, 2012)

\begin{tabular}{|c|c|}
\hline RODZAJ RELACJI & CHARAKTERYSTYKA \\
\hline $\begin{array}{l}\text { RNŻ W "czystej } \\
\text { postaci” }\end{array}$ & $\begin{array}{l}\text { Relacja reportera z miejsca zdarzenia, bez setek, rozmów } \\
\text { z gośćmi, rozmów telefonicznych itp. }\end{array}$ \\
\hline $\begin{array}{l}\text { RNŻ, która } \\
\text { „zapowiada” newsa }\end{array}$ & $\begin{array}{l}\text { RNŻ pełni funkcję ,podprowadzenia” pod materiał, który } \\
\text { ma rozwinąć temat; news jest wówczas także autorstwa } \\
\text { reportera zdającego relacjonującego wydarzenie. }\end{array}$ \\
\hline $\begin{array}{l}\text { News jest } \\
\text { zapowiedzią RNŻ }\end{array}$ & $\begin{array}{l}\text { Na początku jest news, po nim RNŻ- będąca } \\
\text { uzupełnieniem newsa; RNŻ ma wówczas dostarczyć } \\
\text { dodatkowych informacji; nadawcą RNŻ niekoniecznie } \\
\text { jest nadawca newsa. }\end{array}$ \\
\hline RNŻ z setką & $\begin{array}{l}\text { w trakcie RNŻ pojawia się setka. Może być ich kilka w } \\
\text { trakcie jednej RNŻ; setki są urozmaiceniem RNŻ. }\end{array}$ \\
\hline $\begin{array}{l}\text { RNŻ W formie } \\
\text { rozmowy } \\
\text { gościem/gośćmi }\end{array}$ & RNŻ przyjmuje formę dialogu \\
\hline Telefoniczna RNŻ & $\begin{array}{l}\text { telefoniczna relacja korespondenta lub telefoniczna } \\
\text { rozmowa z gościem, który nie mógł przybyć do studia }\end{array}$ \\
\hline $\begin{array}{l}\text { Paralife (zwany } \\
\text { także ,live to tape"). }\end{array}$ & $\begin{array}{l}\text { Imitacja nadawana } \mathrm{w} \text { czasie rzeczywistym. Może więc to } \\
\text { być rozmowa } \mathrm{z} \text { gościem albo relacja reportera nagrana } \\
\text { wcześniej i prezentowana później na antenie. Wówczas } \\
\text { jednak nie mówi się widzom, że materiał emitowany jest } \\
\text { na żywo tylko prowadzący serwis zapowiada, że np. } \\
\text { takim tematem zajmuje się reporter X. }\end{array}$ \\
\hline
\end{tabular}

Zgromadzony materiał tekstowy stanowi stosunkowo niewielki korpus językowy. Obejmuje łącznie 15.850 tokenów (jednostek niepodzielnych - zob. Piasecki (2007)), występujących w 4.744 różnych formach. Korpus ma charakter synchroniczny, materiał pochodzi z okresu od lipca 2010 do lipca 2011.

\subsection{Lista operatorów metatekstowych}

Brak ustalonej jednoznacznie standardowej listy operatorów metatekstowych stwarza konieczność określenia przez badającego materiał własnej typologii. Zdecydowano się przygotować klasyfikację na podstawie propozycji Winiarskiej (2001) Misztal (2010), Żabowskiej (2009), Hylanda (1998), Dahl (2004), Czoski (2011), dodając pewne nowe elementy. W tabeli 3 pokazano listę szukanych wyrażeń z podziałem na klasy wg. klasyfikacji Hylanda (Hyland, 2005; MurDuenas, 2011). 
Agnieszka Czoska, Agata Karaśkiewicz: Operatory metatekstowe w funkcji wskazówek organizacji tekstu mówionego $w$ monologu telewizyjnym

Tabela 3.: Lista szukanych wyrażén

\begin{tabular}{|c|c|c|c|}
\hline Markery logiczne & $\begin{array}{l}\text { markery } \\
\text { endoforyczne }\end{array}$ & $\begin{array}{l}\text { markery aktów } \\
\text { dyskursowych }\end{array}$ & $\begin{array}{l}\text { markery } \\
\text { synonimiczności } \\
\text { i uszczegłówienia }\end{array}$ \\
\hline $\begin{array}{l}\text { ponadto, notabene } \\
\text { dlatego też, dlateg } \\
\text { o, wniosek, jak } \\
\text { widać, jak wynika, } \\
\text { oznacza } \\
\text { to, wynika to, zna } \\
\text { czy to, to znaczy, } \\
\text { to } \\
\text { oznacza, znaczało } \\
\text { by to, } \\
\text { oznaczać to może, } \\
\text { zgodnie z, } \\
\text { jeśli chodzi o, co } \\
\text { do, a'propos, } \\
\text { dodatkowo, } \\
\text { ponadto, poza } \\
\text { tym, w przeciwień } \\
\text { stwie, przeciwnie, } \\
\text { może to oznaczać, } \\
\text { a' propos }\end{array}$ & $\begin{array}{l}\text { Po pierwsze, } \\
\text { pierwszy, } \\
\text { po drugie, drugi, } \\
\text { po trzecie, jak } \\
\text { wspomniano, } \\
\text { jak zostało } \\
\text { powiedziane, } \\
\text { powyżej, } \\
\text { wcześniej, } \\
\text { najpierw, } \\
\text { początkowo, } \\
\text { później, potem, } \\
\text { następnie, } \\
\text { na wstępie, } \\
\text { następny, } \\
\text { kolejny, } \\
\text { na początku, } \\
\text { na koniec, } \\
\text { na zakończenie, } \\
\text { podsumowanie }\end{array}$ & $\begin{array}{l}\text { powiedzmy, } \\
\text { podsumowując, } \\
\text { reasumując, } \\
\text { kończąc, } \\
\text { podsumowanie }\end{array}$ & $\begin{array}{l}\text { Między innymi, } \\
\text { i tak dalej, } \\
\text { mianowicie, } \\
\text { dla przykładu, } \\
\text { na przykład, } \\
\text { przykładowo, } \\
\text { znaczy to, to znaczy }\end{array}$ \\
\hline
\end{tabular}

\subsection{Procedura badawcza}

W programie AntConc w wersji 3.2.4:

1. Przeszukano korpus transkrypcji RNŻ pod kątem występowania słów kluczowych w funkcji metatekstowej.

2. Określono typ (lokalizujące lub retoryczne) operatorów.

3. Oznaczono zasięg i położenie wyrażeń metatekstowych w stosunku do elementów, do których się odnosiły. Operator był oznaczany jako kataforyczny albo anaforyczny jedynie, jeśli możliwe było znalezienie jego obiektu odniesienia, nie uwzględniono operatorów użytych niepoprawnie.

\section{Wyniki badań}

\subsection{Operatory metatekstowe w funkcji organizacji tekstu}

Operatory metatekstowe wystąpiły w korpusie 72 razy na 15,850 słów tekstowych, około 4,5 operatora na 1 tys. słów. 18 RNŻ (na 45) nie zawierało operatorów metatekstowych. Następujące wyrażenia zostały wykorzystane przez nadawców jako leksykalne wskazówki organizacji tekstu (patrz tabela 4): 
Tabela 4.: Lista znalezionych operatorów metatekstowych (w nawiasie liczba wystapień).

\begin{tabular}{|l|l|l|l|}
\hline $\begin{array}{l}\text { markery } \\
\text { logiczne }\end{array}$ & $\begin{array}{l}\text { markery } \\
\text { endoforyczne }\end{array}$ & $\begin{array}{l}\text { markery aktów } \\
\text { dyskursowych }\end{array}$ & $\begin{array}{l}\text { markery } \\
\text { synonimiczności } \\
\text { i uszczegłówienia }\end{array}$ \\
\hline $\begin{array}{l}\text { jeśli chodzi o } \\
(8), \\
\text { jak widać (3), } \\
\text { może to } \\
\text { oznaczać (2), } \\
\text { dlatego (1), } \\
\text { poza tym (1), } \\
\text { a' propos (1) }\end{array}$ & $\begin{array}{l}\text { wcześniej (3), } \\
\text { po drugie (2), } \\
\text { najpierw (1) }\end{array}$ & $\begin{array}{l}\text { podsumowanie } \\
(4), \text { powiedzmy } \\
(1)\end{array}$ & $\begin{array}{l}\text { między innymi (19), } \\
\text { na przykład (18), } \\
\text { i tak dalej (3), } \\
\text { mianowicie (1), } \\
\text { to znaczy (1) }\end{array}$ \\
\hline
\end{tabular}

Znalezione operatory można podzielić ze względu na formę - użyte wyrażenia - na 17 rodzajów.. Najczęściej stosowane były operatory "między innymi” (19 wystąpień) i "na przykład” (18 wystąpień). Najczęściej stosowanymi typami operatorów były markery synonimiczności i uszczegółowienia (32 wystąpienia) oraz markery logiczne (18 wystąpień).

\subsection{Operatory lokalizujące i retoryczne}

Operatory poklasyfikowano także według propozycji Dahl (2004) na lokalizacyjne i retoryczne (patrz tabela 5):

Tabela 5.: Podział znalezionych operatorów na lokalizacyjne i retoryczne.

\begin{tabular}{|l|l|}
\hline $\begin{array}{l}\text { metatekst } \\
\text { lokalizacyjny }\end{array}$ & metatekst retoryczny \\
\hline $\begin{array}{l}\text { po pierwsze (3), } \\
\text { wcześniej (3), po } \\
\text { drugie (2), najpierw } \\
(1)\end{array}$ & $\begin{array}{l}\text { między innymi (19), na przykład (18), jeśli chodzi o (8), } \\
\text { podsumowanie (4), jak widać (3), i tak dalej (3), może } \\
\text { to oznaczać (2), dlatego (1), poza tym (1), a' propos (1), } \\
\text { powiedzmy (1), mianowicie (1), to znaczy (1) }\end{array}$ \\
\hline
\end{tabular}

O wiele liczniejsza (53 vs. 9 wystąpień) okazała się klasa retoryczna, mimo przyjęcia warunku eksplicytności oraz znacznej zawartości metatekstu lokalizującego na liście słów szukanych.

\subsection{Zasięg i położenie operatorów}

Znalezione operatory następnie zostały opisane zgodnie z propozycją Lemarie i in. (2008) na kataforyczne i anaforyczne oraz lokalne i globalne (dotyczące całości danej RNŻ). Wyniki klasyfikacji przedstawiono na wykresach 1 i 2.

Najliczniejszymi typami operatorów były operatory kataforyczne oraz 
Agnieszka Czoska, Agata Karaśkiewicz: Operatory metatekstowe w funkcji wskazówek organizacji tekstu mówionego $w$ monologu telewizyjnym

operatory o zasięgu lokalnym (odnoszące się do przylegających fragmentów tekstu). Wyrażenie "podsumowanie" (retoryczny marker aktu dyskursowego) było najczęściej stosowanym operatorem o zasięgu globalnym (odnoszącym się do całości tekstu lub fragmentów znacznie oddalonych - z różnych części RNŻ), zaś "między innymi” i "na przykład" (retoryczne markery synonimiczności) lokalnym. Te dwa najczęściej stosowane operatory wpłynęły na to, że liczebność metatekstu lokalnego jest wyższa, niż globalnego. Większość użytych w RNŻ operatorów przyjmowała tylko jeden rodzaj zasięgu. $Z$ zasięgiem lokalnym oraz globalnym wystąpiły jedynie „wcześniej” i „może to oznaczać”. Obydwa te rodzaje operatorów przyjmowały także różne położenie.

W położeniu anaforycznym najczęściej stosowano operator "na przykład" (miał on jednak wyższą liczbę wystąpień w położeniu kataforycznym - 12) oraz "podsumowanie (4). W położeniu kataforycznym najczęściej pojawiało się "między innymi" (19 - wszystkie wystąpienia) "na przykład (12) oraz "jeśli chodzi o" (8; zaklasyfikowany powyżej jako retoryczny marker logiczny). Jedynie część operatorów była stosowana zarówno w położeniu kataforycznym, jak i anaforycznym („na przykład”, „po pierwsze”, „wcześniej”, „może oznaczać”, ,po drugie”).

Wykres 1. Liczba wystapień operatorów kataforycznych i anaforycznych (wg. rodzaju i sumarycznie)

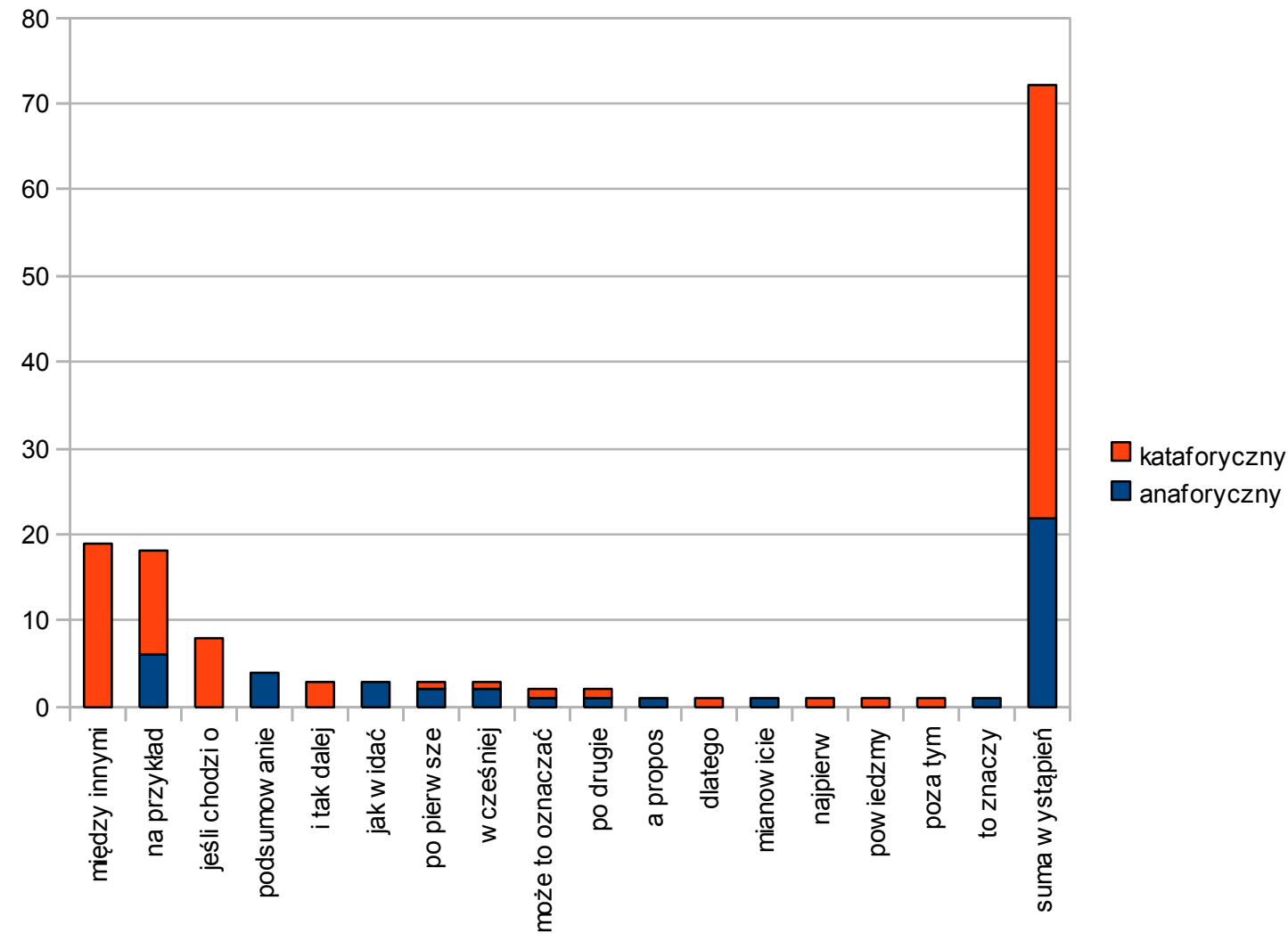


Wykres 2.: Częstość występowania operatorów lokalnych i globalnych (wg. rodzaju i sumarycznie)

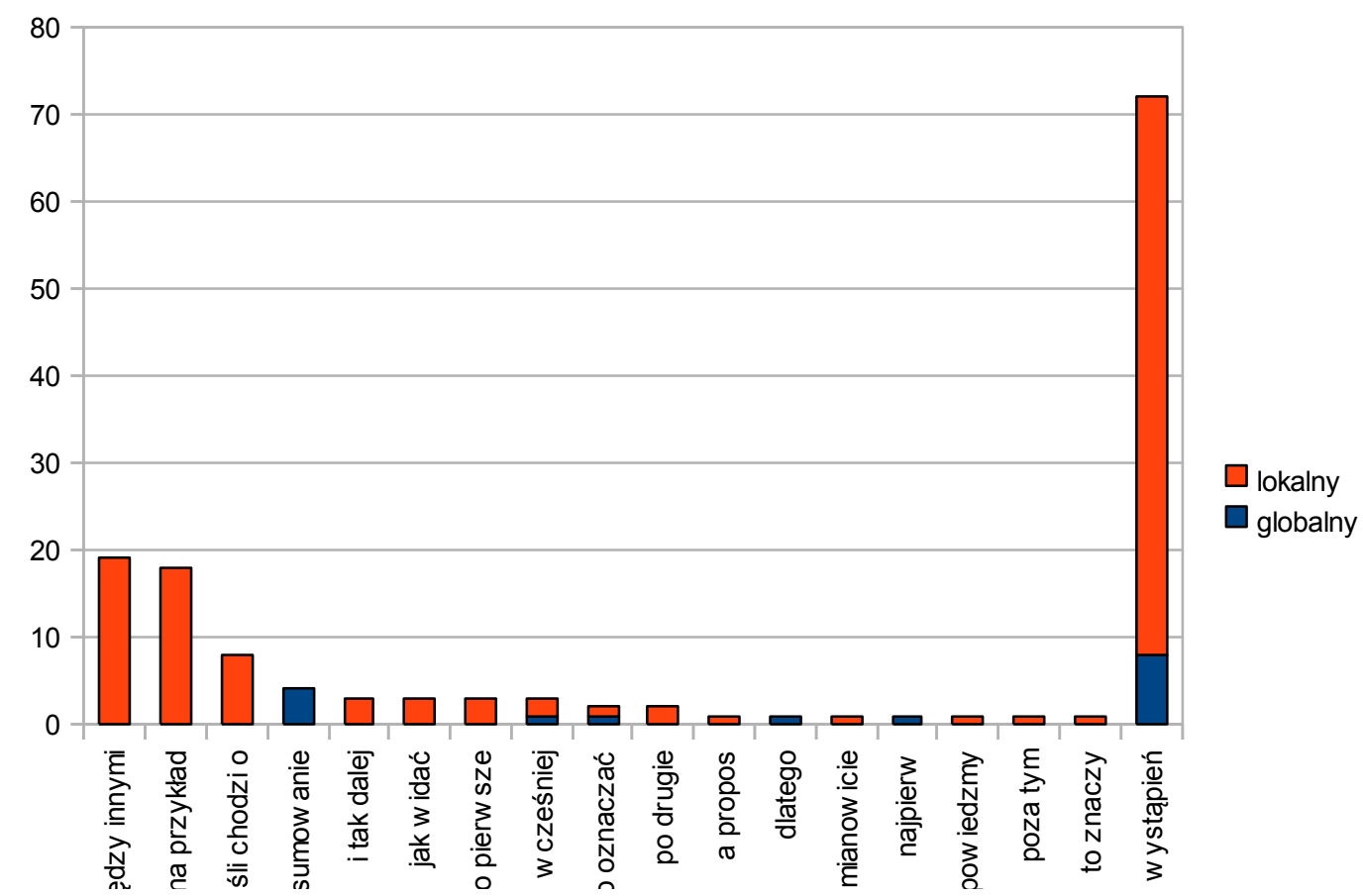

\subsection{Analiza częstości wystąpień operatorów}

Analizy przeprowadzono na wszystkich 45 RNŻ, ale pod uwagę brane były jedynie operatory, które pojawiły się w korpusie przynajmniej raz (tabela 6). Dane o częstości stosowania danych typów metatekstu zostały poddane analizie w programie Weka 3.6.2 (Hall, Frank, Holmes, Pfahringer, Reutemann i Witten, 2009). Zastosowano dostępne tam algorytmy eksploracji danych (data mining), a nie klasyczną analizę statystyczną ze względu na niewielką liczbę znalezionych operatorów.

\subsubsection{Częstość występowania operatorów różnych typów w tym samym tekście}

Do analizy występowania kilku rodzajów operatorów $\mathrm{w}$ jednym tekście zastosowano algorytm Simple Linear Regression (SLR), będący odpowiednikiem regresji liniowej dwóch zmiennych, który wybiera jedną zmienną istotną dla zależnej spośród wszystkich dostępnych. Istotność statystyczną współczynników korelacji sprawdzono dodatkowo obliczając równanie regresji liniowej $\mathrm{w}$ programie IBM SPSS Statistics 20 (w tabeli uwzględniono się jedynie istotne współczynniki - $\mathrm{p}<0,01)$. 
Agnieszka Czoska, Agata Karaśkiewicz: Operatory metatekstowe w funkcji wskazówek organizacji tekstu mówionego $w$ monologu telewizyjnym

Tabela 7.: Wspótwystępowanie operatorów w jednym tekście.

\begin{tabular}{|l|l|l|}
\hline $\begin{array}{l}\text { zmienna zależna (liczba } \\
\text { wystąpień operatora) }\end{array}$ & $\begin{array}{l}\text { zmienna istotna (liczba } \\
\text { wystąpień operatora) }\end{array}$ & $\begin{array}{l}\text { współczynnik } \\
\text { korelacji }\end{array}$ \\
\hline jak widać & między innymi & 0,75 \\
\hline jeśli chodzi o & na przykład & 0,85 \\
\hline po drugie & po pierwsze & 0,84 \\
\hline po pierwsze & po drugie & 0,89 \\
\hline
\end{tabular}

Znalezione korelacje dotyczą współwystępowania operatorów w tekście RNŻ, w/w operatory nie występowały razem jako wyrażenie złożone. Operatory wyliczenia były stosowane rzadko (,,po pierwsze” - 3 wystąpienia, ,po drugie” 2), wobec czego interesujące wydają się jedynie dwie pierwsze relacje. Wszystkie znalezione relacje są silne.

\subsubsection{Zależność między zasięgiem i położeniem operatorów w korpusie}

Algorytm SLR zastosowano także do zbadania współzmienności położenia i zasięgu poszczególnych operatorów (Tabela Z). Wyniki analizy przedstawiono w tabeli 2. Uwzględnione zostały jedynie relacje istotne statystycznie $(p<0,01)$. Wszystkie znalezione zależności są silne.

Tabela 8.: Zależności między zasięgiem i położeniem operatora - SLR

\begin{tabular}{|l|l|l|}
\hline $\begin{array}{l}\text { zmienna zależna } \\
\text { klasa operatora }\end{array}$ & $\begin{array}{l}\text { zmienna istotna - klasa } \\
\text { operatora }\end{array}$ & współczynnik regresji \\
\hline operatory kataforyczne & metatekst lokalny & $\begin{array}{l}0,43 \quad(0,9 \text { dla klasycznego } \\
\text { równania regresji })\end{array}$ \\
\hline operatory anaforyczne & metatekst lokalny & 0,99 \\
\hline operatory globalne & operatory anaforyczne & 0,8 \\
\hline operatory lokalne & operatory kataforyczne & 0,99 \\
\hline
\end{tabular}

\subsubsection{Relacje między zasięgiem i położeniem operatorów w poszczególnych tekstach}

Analizę SLR wykonano także dla danych opisujących liczbę wystąpień operatorów o różnym położeniu i zasięgu oraz sumę operatorów $\mathrm{w}$ poszczególnych tekstach. Znaleziono zależność liniową pomiędzy sumą 
operatorów (zmienna zależna) i liczbą operatorów lokalnych (wskaźnik korelacji $=0,9755)$ oraz słabszą zależność liniową $(0,795)$ pomiędzy liczbą anafor (zmienna zależna) i sumą operatorów w tekście.

$\mathrm{Na}$ powyższych danych wykonano także analizę algorytmem konstruującym drzewo decyzyjne (J48) ze względu na obecność lub brak anafor (mniej licznego typu położenia) jako funkcji zasięgu operatorów i ich sumy w danym tekście. Otrzymane drzewo składało się z 3 reguł wskazujących, że operatory anaforyczne pojawiały się w tekstach, w których wystąpiły więcej, niż 3 operatory (patrz Rysunek 1). W przeciwnym przypadku operatory anaforyczne wystąpiły tylko, jeżeli wśród zastosowanych 1 - 3 operatorów był chociaż jeden operator o zasięgu globalnym. Procent poprawnych zaklasyfikowań wynosi $82 \%$, pole pod krzywą ROC (ROC Area) - 0,81 (model testowano 10-krotnym sprawdzianem krzyżowym), więc model (reguły) nie klasyfikuje przypadków losowo.

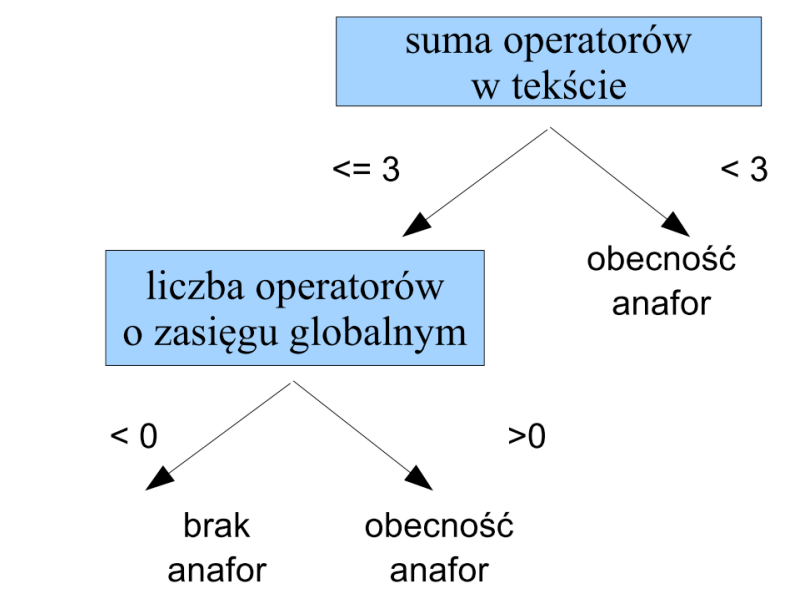

Rysunek 1: Zależność obecności operatorów anaforycznych od ich sumy i zasięgu(drzewo J48)

Algorytm J48 zastosowano także do analizy użycia operatorów o zasięgu globalnym (mniej liczna klasa) jako funkcji ich położenia oraz sumy operatorów w danym tekście, jednak drzewo decyzyjne było stosunkowo rozbudowane (5 reguł dla danych o 5 zmiennych), przy czym poprawność klasyfikacji wynosiła $80 \%$, zaś pole pod krzywą ROC - 0,5 (co świadczy o niskiej poprawności klasyfikacji, bliskiej losowaniu).

Do analizy współwystępowania operatorów w tekstach zastosowano także algorytm Apriori. Algorytm działa na danych nominalnych, w związku z czym dokonano nominalizacji danych (przeprowadzono klasyfikację binarną - operator wystąpił $\mathrm{w}$ danym tekście, lub nie). Algorytm wydobył $\mathrm{z}$ danych kilka interesujących reguł, które można sprowadzić do dwóch:

1. Jeśli w tekście wystąpił operator „po drugie”, wystąpił także „po pierwsze” oraz ,między innymi”.

2. Jeśli w tekście wystąpił operator „miedzy innymi” oraz ,jeśli chodzi o”, 
Agnieszka Czoska, Agata Karaśkiewicz: Operatory metatekstowe w funkcji wskazówek organizacji tekstu mówionego $w$ monologu telewizyjnym

wystąpił także „na przykład”.

Obydwie reguły są spełniane przez 2 teksty i nie są naruszane przez żaden (confidence=1).

\section{Dyskusja wyników}

Hipotezy badawcze postawione w rozdziale 5 miały charakter ilościowy. Hipoteza 1 potwierdziła się. Reporterzy najczęściej stosowali operatory o zasięgu lokalnym. Hipoteza 2 także została potwierdzona - operatory kataforyczne stosowane były częściej, niż anaforyczne. Hipoteza 3 nie znalazła potwierdzenia. W tekstach RNŻ najliczniejsze okazały się markery synonimiczności i uszczegółowienia oraz markery logiczne.

Dalsza dyskusja wyników badania będzie próba interpretacji wyników analiz ilościowych w świetle dostępnej literatury nt metatekstu.

\section{1 (Za)planowanie RNŻ}

Mimo, że RNŻ powstają w czasie realnym, na żywo, ich autorzy nie skupiają się na wskazaniu związków pomiędzy nowymi informacjami (bieżącymi elementami wypowiedzi), a ich otoczeniem tekstowym (co-text), ale przede wszystkim na zapowiadaniu kolejnych fragmentów. Przewaga operatorów kataforycznych może świadczyć o tym, że RNŻ konstruowane są zgodnie z założonym wcześniej planem i postrzegane przez nadawcę jako rodzaj ustalonej wcześniej całości. Wydaje się być to zgodne $\mathrm{z}$ powszechnie przyjętym modelem przedstawiania informacji w mediach (także w RNŻ) opartym na strukturze odwróconej piramidy (Niczyperowicz, 2009). Najważniejsze fakty znajdują się na początku: sygnalizuje się jakie wydarzenie miało miejsce, gdzie i kiedy, dopiero później następuje rozwinięcie tematu, uzupełniane są o wiadomości o kontekście itd.

Okazuje się więc, że pomimo krótkiego czasu na przygotowanie, kompozycja przekazu jest $\mathrm{w}$ pewnym stopniu przez reportera zaplanowana. Wszystkie znalezione $\mathrm{w}$ tekstach RNŻ operatory kataforyczne były następnie realizowane przez nadawcę (w trakcie anotacji korpusu operator był oznaczany jako kataforyczny albo anaforyczny jedynie, jeśli możliwe było znalezienie jego obiektu odniesienia, nie uwzględniono operatorów użytych niepoprawnie).

W odróżnieniu od tekstów pisanych, w RNŻ najczęściej stosowane są wskazówki synonimiczności i uszczegółowienia oraz markery logiczne. Może to wskazywać na to, że jeśli autorzy odwołują się podczas nadawania relacji do założonego $\mathrm{z}$ góry planu, nie traktują go jako struktury złożonej $\mathrm{z}$ poszczególnych, wyróżnionych ściśle elementów (jak w tekstach pisanych (Czoska 2011)), ale skupiają się na relacjach i strukturze retorycznej wypowiedzi (Dahl, 2004). Może to być związane $\mathrm{z}$ kontrolowaniem przebiegu własnej wypowiedzi, lub też wskazywaniem zamierzonej struktury tekstu nadawcy, aby zapewnić, że dobrze zrozumie daną RNŻ (Hyland, 2005).

\subsection{Współwystępowanie operatorów}

W tekstach RNŻ można zaobserwować tendencję (por. tabela 7 oraz wyniki Apriori) nadawców do stosowania dwóch rodzajów operatorów w tym samym tekście: ,jak widać” razem z ,między innymi” oraz ,jeśli chodzi o” z „na 
przykład". Jako że tendencja ta dotyczy wskazówek relacji logicznej i uszczegółowienia, można ją interpretować jako wskaźnik koncentracji nadawcy na wskazywaniu odbiorcy założonej struktury retorycznej komunikatu. Na rzecz tego wniosku przemawia także większa liczba operatorów retorycznych niż lokalizacyjnych (wskazującym strukturę tekstu w sensie układu jego części, bez opisywania wiążących je relacji).

\subsection{Związek zasięgu i położenia operatora}

Wyniki przedstawionych analiz danych pozwalają wskazać silne zależności pomiędzy zasięgiem i położeniem operatorów metatekstowych, stanowiących leksykalne wskazówki struktury tekstu RNŻ (por. tabela 8). Można tu mówić o istotnej statystycznie zależności pomiędzy anaforycznością lub katafotycznością operatora a jego zasięgiem, zwłaszcza w przypadku zależności pomiędzy zasięgiem lokalnym i kataforycznością. W powiązaniu $\mathrm{z}$ analizą współwystąpień wyróżnionych typów operatorów w tekstach wskazują na to, że liczba wskazówek anaforycznych jest proporcjonalna do wskazówek o globalnym zasięgu, zaś kataforycznych - lokalnym. Może to świadczyć o tym (por. także wyniki SLR), że w przeanalizowanych RNŻ nadawcy, jeśli wskazują tło swoich wypowiedzi, to uznają za nie całość dotychczas podanych informacji (operatory anaforyczne o zasięgu globalnym), natomiast zapowiadają pojawienie się nowej informacji bezpośrednio przed jej wprowadzeniem (lokalne operatory kataforyczne). Ponadto częściej wykorzystują wskazówki organizacji tekstu mające na celu wywołanie oczekiwań co do dalszego rozwoju relacji, a nie kontrolowania, czy odbiorca współdzieli z nimi wiedzę tła (w sensie pamięci dyskursu - discourse mememory) oraz wiedzy współdzielonej (Fetzer i Fisher, 2007; Rodriquez, 2007).

\subsection{Styl RNŻ}

Przenalizowane RNŻ cechują się liniową strukturą argumentacji oraz stylem proaktywnym (Ädel, 2006; Dahl, 2004). Może to świadczyć o tym, jak wspomniano wyżej, że autorzy relacji, mimo tego że konstruują je "na bieżąco", mają poczucie, że relacja tworzy ustrukturyzowaną całość i być może utrzymują w trakcie mówienia reprezentację planu lub schematu danej wypowiedzi, do którego realizacji dążą.

Najczęściej stosowane były operatory retoryczne, kataforyczne i o zasięgu lokalnym. Wynik ten pozwala uzupełnić charakterystykę stylu RNŻ: mimo liniowości argumentacja (czy przebieg relacji) może nie być do końca spójny, skoro spójność na poziomie lokalnym jest przez nadawców zwiększana przez użycie operatorów. Może o tym świadczyć także większa liczba operatorów retorycznych, niż lokalizacyjnych - wg. nadawcy podkreślenia i ujednoznacznienia wymagają relacje retoryczne pomiędzy fragmentami tekstu, niż ich wzajemne położenie lub struktura tekstu jako taka (wskazywane operatorami lokalizacyjnymi).

Operatory metatekstowe były stosunkowo często stosowane w przebadanych RNŻ (por. średnia dla krótkich tekstów naukowych w badaniu jednej z autorek wyniosła 5,16 operatora na 1 tyś. słów (Czoska, 2011)) . Może to wskazywać na perswazyjny charakter RNŻ - intencją narratora jest nie tylko zapamiętanie przez 
Agnieszka Czoska, Agata Karaśkiewicz: Operatory metatekstowe w funkcji wskazówek organizacji tekstu mówionego w monologu telewizyjnym

odbiorcę treści relacji, ale także zrozumienie jej w sposób zamierzony tak, by przekazać także wnioski i opinie na temat przekazanych informacji (DafouzMilne, 2011; Hyland, 1998). Jednak wniosek tego typu powinien być dodatkowo poparty badaniem skoncentrowanym na wskazówkach nastawienia nadawcy co do przekazywanej treści.

\section{Podsumowanie i możliwości dalszych badań}

Podjęte badanie pozwoliło na wstępne scharakteryzowanie operatorów metatekstowych występujących w krótkich przekazach reporterskich w postaci RNŻ. Wykazano także, że przekazy tego typu mogą cechować się zaplanowaną organizacją, a reporterzy sygnalizują ją explicite, zwłaszcza aspekt retoryczny struktury komunikatu.

Wnioski uzyskane na podstawie analizy zgromadzonego materiału wymagają dalszych badań $\mathrm{w}$ tym zakresie, które pozwolą na lepsze zrozumienie roli metatekstu $\mathrm{w}$ tekstach pisanych lub mówionych zarówno $\mathrm{z}$ punktu widzenia nadawcy, jak i odbiorcy. Przedstawionych w niniejszej pracy badań nie należy traktować jako pełnego rozstrzygnięcia postawionych na wstępie problemów. Jest to raczej próba poszukiwania kierunku odpowiedzi, a rezultaty obecnego badania mogą być inspiracją do dalszych dociekań w tej dziedzinie.

Jednym $\mathrm{z}$ kolejnych kroków ku precyzyjniejszemu opisowi organizacji krótkich tekstów- wypowiedzi w przekazach informacyjnych, powinno być sprawdzenie innych wskazówek stosowanych przez reporterów celem porządkowania dyskursu. Przeprowadzone tutaj analizy mogłyby zostać uzupełnione o (a) badania rozszerzające listę wyrażeń klasyfikowanych jako metatekstowe, (b) badanie korpusowe w paradygmacie „lexical bundles" (przeszukiwania korpusu pod kątem n-gramów - wyrazów konwencjonalnie występujących razem) skoncentrowane wokół wyłonienia spośród znalezionych klastrów tych, które można zaliczyć do metatekstu. Zgodnie z wiedzą autorek, takie analizy nie były do tej pory prowadzone, zwłaszcza jeśli chodzi teksty mówione. Tymczasem można oczekiwać, że wymienione wyżej klasy wyrażeń stanowią ważne elementy wpływające na zrozumiałość i sposób rozumienia przekazów (Goldman i Rakestraw, 2000; Sanders, Land i Mulder, 2007). Ponieważ operatory metatekstowe nie pozostają bez wpływu na sposób rozumienia komunikatu przez odbiorców, niezbędnym w najbliższej przyszłości krokiem wydaje się również badanie $\mathrm{z}$ uwzględnieniem perspektywy odbiorców: w jaki sposób przetwarzają oraz rekonstruują oni tekst $\mathrm{z}$ udziałem lub pozbawiony opisanych tu operatorów.

Otrzymane wyniki mogą mieć również znaczenie praktycznie. $\mathrm{Na}$ ich podstawie można stworzyć model organizacji przekazu reporterskiego dla opanowujących warsztat dziennikarzy, a w przyszłości być może przygotować odpowiednie oprogramowanie (tzw. chatterbota) automatycznie przekazujące wiadomości.

*Autorki chciałaby podziękować Maciejowi Rasiowi za pomoc w technicznej obsłudze korpusu. 


\section{Investigationes Linguisticae, vol. XXVI}

\section{Bibliografia}

Ädel, A. (2006). Metadiscourse in L1 and L2 English. John Benjamins Publishing Company.

Czoska, A. (2011). Klasyfkacja operatorów metatekstowych i częstość ich występowania w krótkich tekstach naukowych w języku polskim. Investigationes linguisticae, XXIII.

Bobryk, J. (2005). Jak tworzyć rozmawiając. Skuteczność rozmowy. wyd. PWN.

Boyd, A. (2006). Dziennikarstwo radiowo-telewizyjne. Techniki tworzenia programów informacyjnych. Wydawnictwo Uniwersytetu Jagiellońskiego.

Fetzer, A. i Fischer, K. (2007). Introduction. w: Anita Fetzer i Kerstin Fisher (red.). Lexical markers of common grounds. Lavoisier.

Fraser, B. (1999). What are discourse markers? Journal of pragmatics, 31, 931 - 952.

Goldman, S. R. i Rakestraw, Jr. J. A.(2000). Structural Aspects of Constructing Meaning from Text w: Kamil, M. L. (red.) Handbook of Reading Research: Volume III. Lawrence Erlbaum Associates.

Grabias, S. (1997). Język w zachowaniach społecznych. Wyd. UMSC, Lublin.

Dahl, T. (2004). Textual metadiscourse in research articles: a marker of national culture or of academic discipline? Journal of pragmatics, 36, 1807-1825

Hall, M., Frank, E., Holmes, G., Pfahringer, G., Reutemann, P. i Witten, I. H.(2009) The WEKA Data Mining Software: An Update. SIGKDD Explorations, 1(11).

Hunston, S.i Thompson, G. (2000). Evaluation in Text. OUP.

Hyland, K. (1998). Persuasion and context: the pragmatics of academic metadiscourse, Journal of pragmatics, 30 .

Hyland, K.(2005). Metadiscourse. Exploring interaction in Writing. Continuum.

Jachimowska, K. (2005). Tekst jako element komunikatu telewizyjnego (na materiale programów publicystycznych). Wydawnictwo Uniwersytetu Łódzkiego.

Jacobson, R. (1989). Poetyka w świetle językoznawstwa w: W poszukiwaniu istoty języka. Wybór pism, Tom 2. Państwowy Instytut Wydawniczy.

Legutko, P. i Rodziewicz, D. (2007). Gra w media. Między informacją a deformacją. Stentor.

Lemarié, J., Lorch, Jr. R. F., Eyrolle, H. i Virbel, J. (2008). SARA: A Text-Based and Reader-Based Theory of Signaling. Educational Psychologist, 1(43), 27-48.

Lorch, Jr. R. F., , Lemarié, J. i Grant, R. A. (2011). Three Information Functions of Headings: A Test of the SARA Theory of Signaling. Discourse processes, 48, 139160.

Lubaś, W. (1979). Społeczne uwarunkowania współczesnej polszczyzny. Wydawnictwo Literackie.

Miodunka, A. i Ropa, A. (1979). Z zagadnień socjolingwistycznego opisu sytuacji na przykładzie sytuacji telewizyjnej. w: Lubaś, W. (red.) Socjolingwistyka 2, Prace Naukowe UŚ 287.

Misztal, B.(2010). Strategie metadyskursywne w internecie. Studia medioznawcze, 3(42), $114-132$.

Montgomery, M.(2007). The Discourse of Broadcast News. Routledge.

Mukarovsky, J. (1970). Dwa studia o dialogu. Przeł. Mayen, J. w: Wśród znaków i struktur. Państwowy Instytut. Wydawniczy.

Mur-Dueñas, P. (2011) An intercultural analysis of metadiscourse features in research articles written in English and in Spanish. Journal of pragmatics, 43, 3068-3079.

Niczyperowicz, A. (2001). Dziennikarstwo od kuchni. TS Wydawnictwo.

Piasecki, M. (2007). Cele i zadania lingwistyki informatycznej. W: Stalmaszczyk, P. Metodologie językoznawstwa. Współczesne tendencje i kontrowersje. LEXIS. 
Agnieszka Czoska, Agata Karaśkiewicz: Operatory metatekstowe w funkcji wskazówek organizacji tekstu mówionego w monologu telewizyjnym

Rodriguez, C. (2007). A Common Ground for Knowledge through Knowledge of Language: A computational Research of Consensus-Based Meaning in Scientific Papers. w: Fetzer, A. i Fisher, K. (red.). Linguistic markers of common grounds. Lavoisier.

Ropa, A. (1979). Próba klasyfikacji występujących w telewizji odmian języka. Zeszyty Prasoznawcze, XX, 41-48.

Saeed, J.I. (1997). Semantics. Blackwell.

Sanders, T., Land, J. i Mulder, G. (2007). Linguistic markers of coherence improve text comprehension in functional contexts. Information Design Journal, 15(3), $219-235$.

Wilkoń, A. (2002) Spójność i struktura tekstu. UNIVERSITAS.

Winiarska, J.(2001). Operatory metatekstowe w dialogu telewizyjnym. Universitas.

Uszyński, J. (2004). Telewizyjny pejzaż genologiczny. Telewizja Polska S.A.

Żabowska, M.(2009). Hierarchia wyrażeń metatekstowych. Linguistica copernicana, 2(2). 